\title{
THE BACTERIAL FLORA OF THE AIR OF OCCUPIED ROOMS
}

\author{
By R. E. O. WILLIAMS, O. M. LIDWELL \\ AND ANN HIRCH \\ Air Hygiene Laboratory, Central Public Health Laboratory, \\ Colindale, London, N.W. 9
}

(With 2 Figures in the Text)

The hypothesis that the transmission of upper respiratory disease takes place largely through the agency of air-borne particles of small size has stimulated the development during the last two decades of a variety of instruments for estimating the numbers of air-borne bacteria and has revived the suggestion that estimations of this kind might be used as an index of the healthiness or unhealthiness of the environment. However, no detailed study has appeared of the factors affecting the numbers of the various bacterial species to be found in the air of occupied rooms, nor has any attempt been made to relate such bacterial counts to the sickness experience of persons occupying the rooms. During an investigation of the value of air disinfection with ultra-violet irradiation in a group of London primary schools, we made numerous counts of the bacteria in the air of the classrooms, and also observed a large number of environmental factors. In this paper we report an analysis of the relationships between the bacterial counts and the environmental conditions. An analysis of the relation between the bacterial counts and the sickness experience of the children is presented separately (Reid, Lidwell \& Williams, 1956).

\section{SOURCE AND METHODS}

The investigation of the value of the ultra-violet irradiation was made in six primary schools in the Middlesex borough of Southall from January 1947 to December 1949 (see Air Hygiene Committee, 1954, which contains a detailed account of our technical methods). On each day during the nine school terms, visits were made to two classrooms in each of two schools. These visits took place during school hours and, so far as possible, the class routine proceeded undisturbed during the visit. Samples of air-borne bacteria were collected, with a slit-sampler and exposed culture plates, for determination of $(a)$ the total number of viable aerobic bacteria growing on serum agar media in $20 \mathrm{hr}$. at $37^{\circ} \mathrm{C}$. ('general flora'), and $(b)$ the number of 'total streptococci' and of Streptococcus salivarius, using the selective medium and techniques described by Williams \& Hirch (1950). The epithet salivarius, used by Sherman, Niven \& Smiley (1943) to refer to the levan-producing streptococci, is retained for consistency with the earlier reports on this investigation, although the epithet 'hominis' may be more correct (Williams, 1956). At each visit estimates were also made of the ventilation rate of the room, by measuring the decay rate of the tracer acetyl-acetone sprayed into the air (Lidwell \& Lovelock, 1946), 
and, using an arbitrary scale, records were made of the amount of talking and activity among the children. Measurements were made of the wet- and dry-bulb temperatures in the classroom and outdoors using a sling hygrometer, and of the air velocity using a kata-thermometer. The wind direction and its approximate velocity were estimated. Measurements of rainfall were obtained, by courtesy of the Air Ministry, from the records of London Airport, which is $3 \frac{1}{2}$ miles distant from the schools, and measurements of solar radiation were provided by Kew Observatory.

The frequency distribution of the bacterial counts was found to approximate to the log-normal form. For analysis, the counts were therefore transformed to a logarithmic scale and all computations were made on the transformed, logarithmic, figures.

For the sake of completeness we have included in this paper some results from various other unpublished investigations, mostly in busy offices and shops, where bacterial air-sampling surveys have been made with substantially the same methods as in the schools; and we have cited the results obtained in boot and shoe factories (Hirch, 1951) and in underground trains (Williams, Hirch \& Lidwell, 1950).

\section{RESULTS}

\section{Types of bacteria found in air samples}

Twenty-five to forty colonies from each of twenty-nine serum agar air plates from unirradiated classrooms were subcultured on to blood agar for more precise identification (Table I).

Table 1. Bacterial species comprised in general flora of school classrooms (based on a total of 930 colonies from 29 air samples)

\begin{tabular}{lcc}
\multicolumn{1}{c}{ Bacteria } & $\begin{array}{c}\text { Count in } \\
\text { cols./cu.ft. }\end{array}$ & $\begin{array}{c}\text { Count as a } \\
\text { percentage of } \\
\text { total count }\end{array}$ \\
Micrococci & $35 \cdot 04$ & $81 \cdot 6$ \\
Diphtheroid organisms & $2 \cdot 94$ & $6 \cdot 8$ \\
Aerococci & $1 \cdot 41$ & $3 \cdot 3$ \\
Streptococci & $1 \cdot 34$ & $3 \cdot 1$ \\
Coliform organisms & $1 \cdot 15$ & $2 \cdot 7$ \\
Aerobic spore-bearing organisms & $0 \cdot 42$ & $1 \cdot 0$ \\
Staph. aureus & $0 \cdot 12$ & $0 \cdot 3$ \\
Others & $0 \cdot 54$ & $1 \cdot 3$ \\
Total flora & $42 \cdot 96$ & $100 \cdot 1$
\end{tabular}

The term 'micrococci' is used for all Gram-positive cocci that are not streptococci, coagulase-positive staphylococci, nor aerococci. The last-named is a Grampositive coccus, not a streptococcus, distinguished from the micrococci chiefly by its ability to grow in the presence of 1:500,000 crystal violet, and to produce greening of blood agar (Williams, Hirch \& Cowan, 1953). Micrococci predominated over all other types, and although no formal classification of the micrococci was attempted it was obvious that a great many colonial varieties were present. None of the other groups--diphtheroid, coliform and aerobic spore-bearing organisms- 
was present in large numbers. Although in this comparatively small sample aerococci and streptococci were about equally frequent, aerococci were usually present in larger numbers than streptococci.

Varieties of streptococci. A detailed analysis was also made of the types of streptococci isolated on the selective medium (Table 2). Viridans-type streptococci and Str. salivarius, both typical of those found in the normal mouth, were predominant, but enterococci (i.e. bile-tolerant streptococci with the typical colonial appearance) formed $20 \%$ of the total. $\beta$-haemolytic streptococci were rare.

\begin{tabular}{|c|c|c|}
\hline & $\begin{array}{l}\text { Counts in } \\
\text { cols./cu.ft. }\end{array}$ & $\begin{array}{l}\text { Count as a percentage } \\
\text { of total streptococci }\end{array}$ \\
\hline Viridans-type streptococci & 0.51 & $44 \cdot 7$ \\
\hline Str. salivarius & $0 \cdot 29$ & $25 \cdot 5$ \\
\hline Enterococci: $\alpha$-haemolytic & $0 \cdot 17)$ & $14 \cdot 9)$ \\
\hline$\beta$-haemolytic & $0.01\} 0.23$ & $0.9\} 20 \cdot 2$ \\
\hline Non-haemolytic & 0.05 & $4 \cdot 4$ \\
\hline $\begin{array}{l}\text { Non-haemolytic streptococci not } \\
\text { Str. salivarius }\end{array}$ & 0.08 & $7 \cdot 0$ \\
\hline$\beta$-haemolytic streptococci & $0 \cdot 03$ & $2 \cdot 6$ \\
\hline Total streptococci & $1 \cdot 14$ & $100 \cdot 0$ \\
\hline
\end{tabular}

N.B. The mean total count on the selective plates from which these streptococci were isolated was $7 \cdot 16$ colonies/cu.ft., of which $4 \cdot 95 / \mathrm{cu} . \mathrm{ft}$. were aerococei, and the remainder, apart from the streptococci, were other micrococci, coliform and aerobic spore-bearing organisms.

\section{Average levels of air-borne bacterial contamination}

A survey of the numbers of bacteria-carrying particles found in the air is given in Table 3. The variation about the average values was considerable. Thus in the infant classrooms with a mean general count of 79 colonies/cu.ft. the range that included $95 \%$ of the observations was from 25 to 251 colonies/cu.ft. The comparable figures for the junior classrooms were 58 colonies/cu.ft., with a $95 \%$ range from 19 to 182 colonies/cu.ft. Factories, clerical offices and even underground trains during the rush hour all had lower counts than these.

The streptococcal counts showed larger differences than the general counts between different places and also more variation between samples at any one place; they were highest in the schools and lower, or very much lower, elsewhere.

\section{Factors influencing the bacterial count in the air of schoolrooms}

As a preliminary, we calculated correlation coefficients between the bacterial counts and a number of factors which might be supposed to influence them. These factors included: the outside air temperature, the temperature difference between the classroom and the outside air, the relative humidity outside, the relative humidity inside, rainfall on the day of the visit, rainfall over the previous 7 days, solar radiation on the day of the visit, solar radiation over the previous 7 days, the external wind velocity, the degree of window opening, the ventilation rate, the number of children in the room, the amount of talking by the children, the amount 


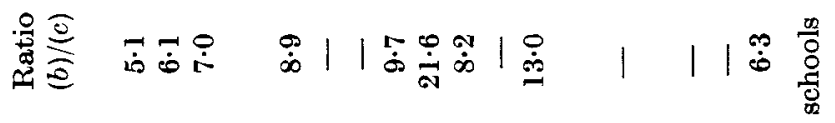

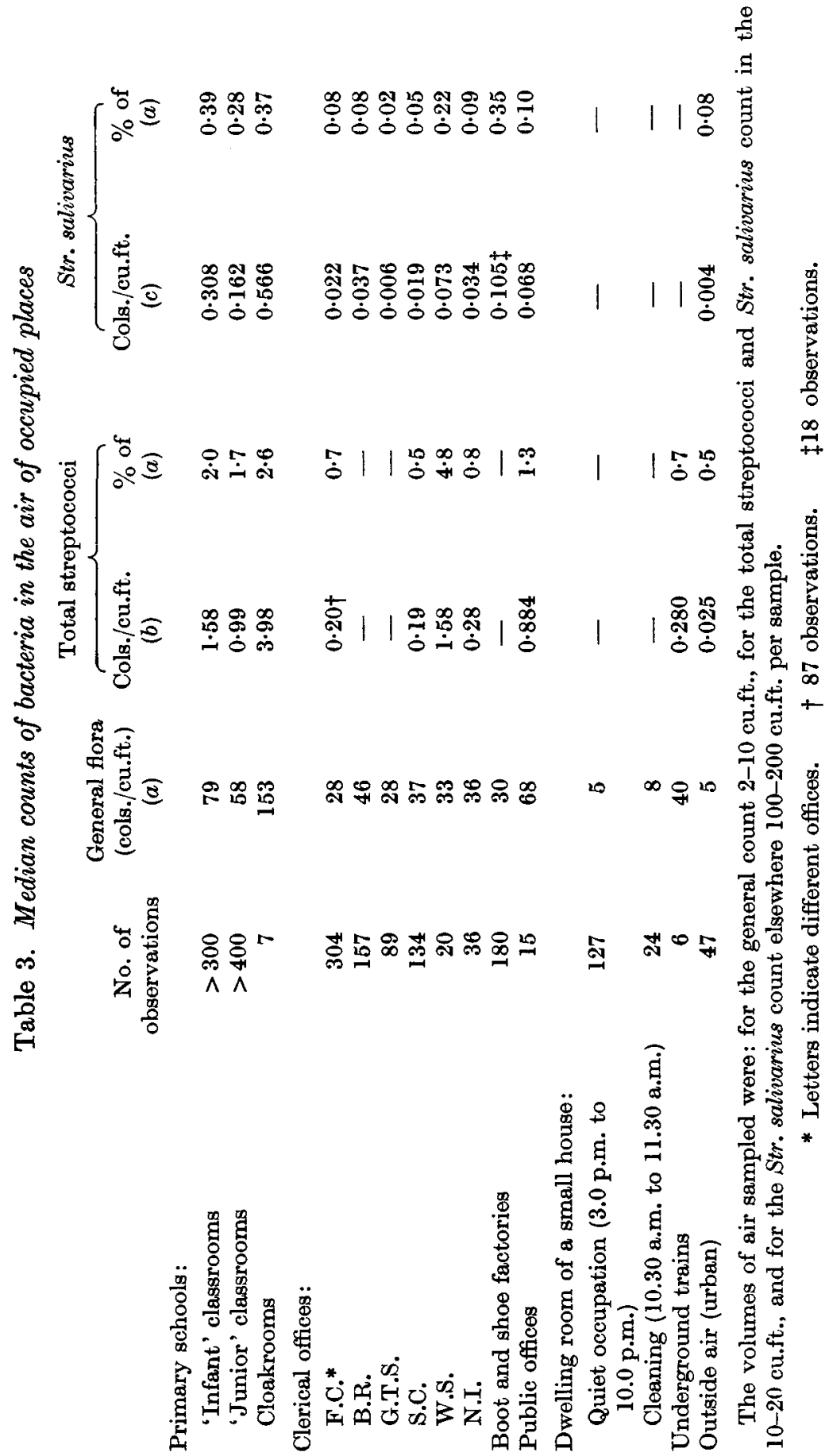


of activity of the children. The effect of outdoor humidity and of window opening was examined separately for ground-floor and first-floor classrooms.

It seemed on inspection of the figures obtained that activity, talking, ventilation rate, relative humidity inside the classrooms and solar radiation on the day of the visit (which partly serves as an index of seasonal effects) were the factors most worth further study. Partial correlation coefficients between these five factors and counts of general flora and of Str. salivarius were therefore computed for the four groups of classrooms defined by distinguishing between infant and junior departments and between irradiated and unirradiated rooms. A total of 1022 sets of observations were available for this analysis.

It was clear that talking, activity and ventilation were by far the most important factors influencing the bacterial counts, but before discussing the detailed analysis based on these three factors it will be convenient to deal with a few other points.

The multiple correlation coefficients derived from the partial correlation coefficients showed that the proportion of the total variance accounted for by the five factors, activity, talking, ventilation, humidity and solar radiation, ranged from 13 to $28 \%$ for the general flora and from 2 to $16 \%$ for Str. salivarius. The numbers of Str. salivarius colonies counted on individual samples were small enough to introduce a random sampling variance of between 20 and $40 \%$ of the total variance actually observed, so that the smaller proportion of the variance in the streptococcal counts accounted for by the factors correlated is not surprising. We have not been able to account for any appreciable part of the residual variance by any of the other observations recorded at the classroom visits. An analysis by classrooms introducing mean class age as a variable showed that this accounted for little if any additional variance. The differences in the median bacterial counts between the school departments, including the junior/infant divisions, were well accounted for by the differences in the observed levels of talking, activity and ventilation. However, variations in the nasal and oral flora of the children, unrepresentative sampling within the rooms, imperfect appreciation and recording of the relevant action of talking and movement must, among other unrecorded causes, have contributed to the variance.

The partial correlation coefficients (fourth order) between solar radiation and general flora were appreciable (between +0.131 and +0.285 in the four different groups of classrooms); those between solar radiation and Str. salivarius, however, were small and negative (between -0.002 and $-0 \cdot 147$ ). This difference, if real, may be due to a greater dispersal of dust in the summer months, increasing the numbers of air-borne saprophytic organisms, contrasted with an increased tendency to coughing and sneezing, raising the streptococcal count, in the winter months. The partial correlation coefficients between relative humidity and general flora were also appreciable and positive (between +0.082 and +0.244 ), which may reflect a seasonal effect similar to that suggested above, since the relative humidity indoors is higher during the summer months. Those between relative humidity and Str. salivarius were insignificant (between +0.041 and $+0 \cdot 058$ ). 


\section{The effect of activity, talking and ventilation}

The correlations between the bacterial counts and the three remaining factors, namely, activity, talking and ventilation, showed several points of interest, and the partial regression equations for the bacterial counts on these were evaluated for five groups of organisms (Table 4). Since the number of observations available for analysis was considerably reduced by the requirements of the simultaneous bacterial and other observations, and examination of individual classroom records showed that infant and junior classrooms could be regarded as being derived from a single population, the results from the infant and junior departments were combined. The combination of departments and the omission of the indoor relative humidity and solar radiation from the factors correlated did not appreciably reduce the multiple correlation coefficient. The data were derived entirely from the last 2 years of the experiment, and the employment of more uniform observational techniques doubtless increased their homogeneity.

Table 4. Coefficients of the standard partial regression equations for bacterial count on activity, talking and ventilation

\begin{tabular}{|c|c|c|c|c|c|}
\hline School group & Organism & Activity* & Talking* & Ventilation* & $\begin{array}{c}\text { Multiple } \\
\text { correlation } \\
\text { coefficient }\end{array}$ \\
\hline \multirow{5}{*}{$\begin{array}{l}\text { Unirradiated } \\
(N=243)\end{array}$} & Str. salivarius & $0 \cdot 15$ & $0 \cdot 42$ & $-0 \cdot 17$ & 0.46 \\
\hline & Mouth streptococci & 0.05 & $0 \cdot 33$ & -0.06 & $0 \cdot 36$ \\
\hline & General flora & $0 \cdot 17$ & $0 \cdot 22$ & -0.28 & $0 \cdot 43$ \\
\hline & Aerococci & $0 \cdot 30$ & $0 \cdot 14$ & $-0 \cdot 26$ & 0.45 \\
\hline & Enterococci & $0 \cdot 13$ & $0 \cdot 10$ & -0.01 & $0 \cdot 20$ \\
\hline \multirow{5}{*}{$\begin{array}{r}\text { Irradiated } \\
(N=229)\end{array}$} & Str. salivarius & $0 \cdot 13$ & $0 \cdot 16$ & -0.08 & $0 \cdot 26$ \\
\hline & Mouth streptococci & $0 \cdot 15$ & $0 \cdot 14$ & $-0 \cdot 12$ & $0 \cdot 28$ \\
\hline & General flora & $0 \cdot 20$ & $0 \cdot 15$ & $-0 \cdot 24$ & 0.40 \\
\hline & Aerococci & $0 \cdot 29$ & $0 \cdot 16$ & $-0 \cdot 25$ & $0 \cdot 48$ \\
\hline & Enterococci & $0 \cdot 18$ & $0 \cdot 09$ & -0.13 & $0 \cdot 27$ \\
\hline
\end{tabular}

* The standard errors of these coefficients are all similar in magnitude and lie between 0.06 and $0 \cdot 08$.

Table 4 is best considered in conjunction with Table 5 , which summarizes certain other information concerning the five groups of organisms included in Table 4. The numerical values given in Table 5, and repeated in Table 6, for the equivalent particle diameters (i.e. the diameters of spherical particles of unit density having the same settling rate in air) are subject to considerable uncertainty, but the order and the relative magnitude of the differences should be reliable.

The counts of streptococci, which were found on larger air-borne particles, were only moderately affected by ventilation. In the unirradiated schools they were, however, strongly correlated with talking, and this, coupled with the known presence of the streptococci in the upper respiratory tract of the children, suggests that in this group of schools the air-borne streptococci are principally derived directly from mouth spray. In the irradiated schools, however, the strong regression on talking was absent, leaving smaller regression coefficients on both activity and talking, which were of the same order as those found between these 
factors and the general flora, aerococci and enterococci. The irradiation at the same time greatly reduced the number of streptococci found in the air. These considerations taken together suggest that the streptococci in the air may have been derived from two sources: some of them were derived directly from the mouth; these formed the greater part of the streptococci found in the air of the control

Table 5. Relative size of air-borne particles, effect of irradiation and occurrence on various sites of different micro-organisms

\begin{tabular}{|c|c|c|c|c|c|c|}
\hline \multirow[b]{3}{*}{ Organism } & \multirow{2}{*}{\multicolumn{2}{|c|}{$\begin{array}{c}\text { Estimated equiva- } \\
\begin{array}{c}\text { lent particle } \\
\text { diameter }(\mu)^{*}\end{array}\end{array}$}} & \multirow{3}{*}{$\begin{array}{l}\text { Reduction in } \\
\text { air count by } \\
\text { ultra-violet } \\
\text { irradiation }\end{array}$} & \multirow{3}{*}{$\begin{array}{c}\text { Upper } \\
\text { respira- } \\
\text { tory } \\
\text { tract }\end{array}$} & \multicolumn{2}{|l|}{ Found } \\
\hline & & & & & & \\
\hline & $\begin{array}{l}\text { Control } \\
\text { schools }\end{array}$ & $\begin{array}{l}\text { Irradiated } \\
\text { schools }\end{array}$ & & & Clothes & Floor \\
\hline Str. salivarius & 21 & 26 & considerable & yes & yes & yes \\
\hline Mouth streptococci & 24 & 24 & considerable & yes & yes & yes \\
\hline General flora & 13 & 14 & slight & no & yes & yes \\
\hline Aerococci & 15 & 17 & slight & no & yes & yes \\
\hline Enterococci & 19 & 21 & slight & no & rarely & yes \\
\hline
\end{tabular}

* The diameter of a spherical particle of unit density calculated to have the same settling rate in air. The estimate is derived from the ratio of the mean slit sampler count (colonies per cu.ft.) to the mean settling plate count (colonies/sq.ft./min.) (Bourdillon, Lidwell \& Lovelock, 1948, appendix II).

Table 6. Relationship between particle size and the effect of ventilation on the bacterial count

\begin{tabular}{|c|c|c|c|c|}
\hline \multirow[b]{2}{*}{ Organism } & \multirow[b]{2}{*}{ School group } & \multirow[b]{2}{*}{$\begin{array}{l}\text { Estimated equivalent } \\
\text { particle diameter }(\mu)\end{array}$} & \multicolumn{2}{|c|}{$\begin{array}{l}\text { Partial regression } \\
\text { coefficients }\end{array}$} \\
\hline & & & Observed & Calculated \\
\hline \multirow[t]{2}{*}{ General flora } & Control & 13 & $-0 \cdot 27$ & -0.59 \\
\hline & Irradiated & 14 & -0.23 & -0.58 \\
\hline \multirow[t]{2}{*}{ Aerococci } & Control & 15 & $-0 \cdot 30$ & -0.54 \\
\hline & Irradiated & 17 & $-0 \cdot 29$ & $-0 \cdot 50$ \\
\hline \multirow[t]{3}{*}{ Enterococci } & Control & 19 & -0.01 & -0.42 \\
\hline & Irradiated & 21 & $-0 \cdot 16$ & -0.41 \\
\hline & Control & 21 & -0.23 & -0.39 \\
\hline Mouth streptococei & Control & 24 & -0.12 & $-0 \cdot 32$ \\
\hline Str. salivarius & Irradiated & 24 & -0.17 & $-0 \cdot 32$ \\
\hline Str. salivarius & Irradiated & 26 & -0.05 & $-0 \cdot 29$ \\
\hline
\end{tabular}

The calculated regression coefficients are derived from the relationship

$$
\text { Count } \propto \frac{1}{\text { ventilation rate }+ \text { sedimentation rate }},
$$

using the mean values of the ventilation rates and values of the sedimentation rate derived from the equivalent particle diameters (Bourdillon et al. 1948, appendix II).

schools and were sensitive to the irradiation. But, in addition, some of the air-borne streptococci were probably dispersed from secondary reservoirs in the form of clothing, and possibly floor dust, and these may have been more resistant to irradiation.

The general flora, aerococci and enterococci were not sensitive to irradiation, and their regression coefficients were similar in the irradiated and unirradiated groups. 
Both general flora and aerococci show a strong negative regression on ventilation and generally similar regressions on activity and talking. These organisms are probably dispersed into the air from secondary reservoirs, principally clothing, and it seems likely that our assessments of talking and activity did not distinguish between talking and those small gestures, associated with talking, that dislodged these organisms from clothing.

The data for the enterococci are, probably owing to the smaller numbers present, less precise than those for the other two groups. They differ also in the much smaller regression coefficient on ventilation. This is probably, to some extent, a consequence of the larger size of the air-borne particles with which they are associated.

\section{The effect of particle size}

The relation of the size of the bacteria-carrying particles to the influence of ventilation on their numbers in the air is illustrated more fully by the results given in Table 6. It will be noticed that the observed regression coefficients are about, or less than, half those which have been calculated on the simplest assumptions of a steady dispersal of bacteria-carrying particles into a room which is ventilated with clean air at a uniform rate and within which the air is perfectly mixed. Two factors in particular may contribute to this difference, first the appreciable errors in the determination of the ventilation rate and secondly the fact that the ventilating air was not itself free from air-borne bacteria. (The calculated regression is not strictly linear, but the effect of this does not appear to be very great.) We have no means of measuring the magnitude of either of these factors, but calculations based on possible values suggest that together they could account for the greater part of the differences.

The apparent particle size is itself affected by several factors. The effect of irradiation is apparently selectively exercised on the smaller particles so that the survivors are associated with a slightly larger equivalent particle diameter (Table 6). The effect, though small, is consistent in all the bacterial groups. Ventilation would be expected to be similarly selective in reducing the proportion of smaller particles which have a slower settling rate. For the general flora, this expectation was realized (Fig. 1). No similar effect could be observed with Str. salivarius, which may reflect either the carriage of these organisms on particles more homogeneous in size than the general flora, or the reduced accuracy of the determination of size for these organisms, or both.

The particle size for general flora was slightly increased as the level of activity increased (Fig. 2), presumably because the more vigorous movements were effective in dispersing larger particles. No such effect would be expected with Str. salivarius if these are principally derived directly from mouth spray and none is shown, although, again, the accuracy of the measurements of relative particle size is not high.

The recorded levels of activity and talking were considerably lower in the junior than in the infant classrooms, and it is therefore possible that the proportions of streptococci derived directly from mouth spray or indirectly from secondary reservoirs such as clothing differed in the two groups. If the streptococci derived 


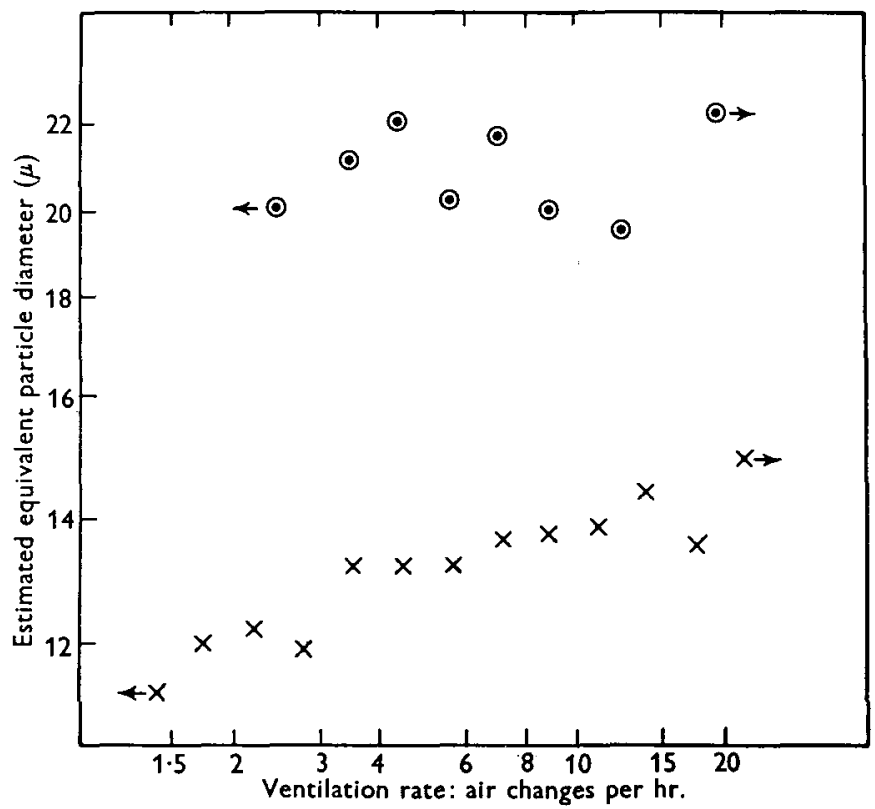

Fig. 1. The relation of ventilation to the size of the air-borne bacterial particles in schoolrooms. $\odot=$ Str. salivarius, $x=$ general flora. The arrows indicate that the range of values included in that point extends to include all observed values in the direction of the arrow. The total number of observations was about 1000 for Str. salivarius and 1200 for general flora; the numbers for each point on the graph are not less than 90 , or 17 respectively.

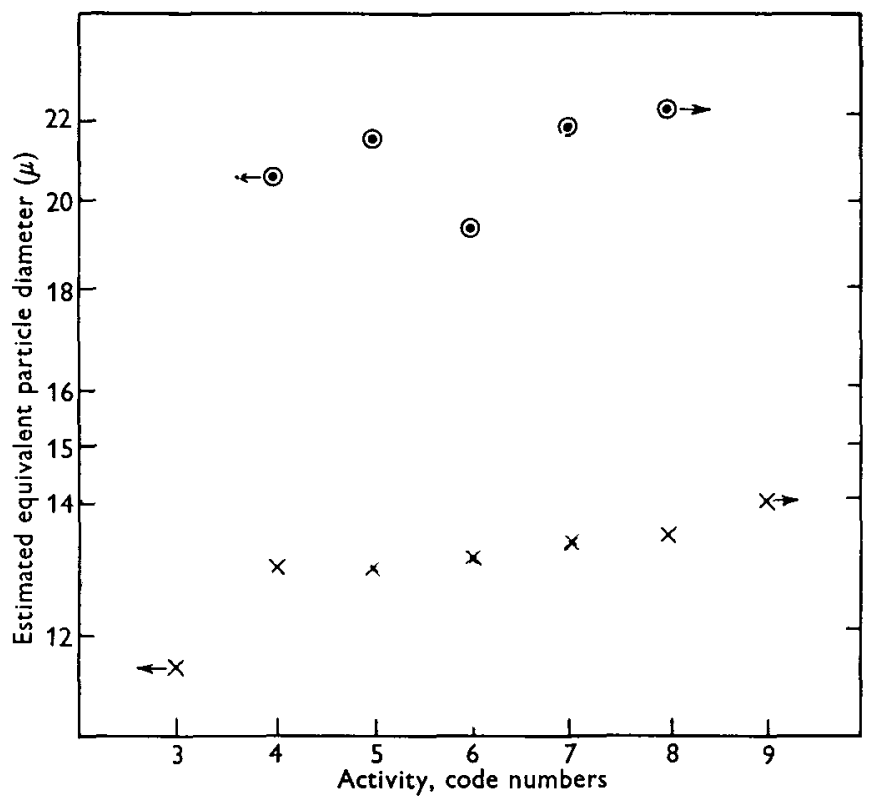

Fig. 2. The relation of the amount of the children's activity to the size of the air-borne bacterial particles in schoolrooms. Conventions and total numbers of observations as in Fig. 1; the numbers contributing to individual points on the graph are not less than 150 for Str. salivarius or 14 for general flora. 
from the secondary reservoirs were more resistant to the irradiation, a higher proportion of direct mouth-spray streptococci in the air would be associated with a bigger proportionate effect of irradiation on the count of streptococci.

The effect of irradiation was in fact greater in the infant departments by about $25 \%$ for the mouth streptococci and about $50 \%$ for Str. salivarius (Table 7). These differences are close to those calculated from the regression equations corresponding to the standard regression equations of Table 4 using the values of activity, talking and ventilation for the infant and junior departments which are given in Table 7. The higher levels of talking in the infant departments were in fact responsible for the calculated differences.

\section{Table 7. Differences in the effect of irradiation on the bacterial counts} in the junior and infant departments

Mean value of activity (code no.)

$\begin{array}{cc}\text { Junior } & \text { Infant } \\ \mathbf{5 \cdot 9} & \mathbf{6 \cdot 8} \\ \mathbf{5 \cdot 8} & \mathbf{7 \cdot 6} \\ \mathbf{6 \cdot 6} & \mathbf{5 \cdot 9}\end{array}$

Mean value of talking (code no.)

Mean value of ventilation (air changes per hour)

$6 \cdot 6$

Mean count in control departments

Mean count in irradiated departments,

(F) : for total mouth streptococci $2 \cdot 04$

$2 \cdot 44$

$3 \cdot 77$

for Str. salivarius

obs.

Ratio, $F_{\text {intant }} / F_{\text {junior }}$ :

for total mouth streptococci $\mathbf{1 \cdot 2 4}$

for Str. salivarius

$1 \cdot 55$

calc.

$1 \cdot 28$

1.50

The calculated values of $F_{\text {infant }} / F_{\text {janior }}$ are derived from the regression equations corresponding to the standard regression coefficients of Table 4.

\section{DISCUSSION}

Interest in the numbers of streptococci in the air derives from the assumption, originally set out by Gordon (1904), that they can be used to indicate the extent to which the air is polluted from the upper respiratory tract. Viridans-type streptococci are well known to be universally present in the mouth; Str. salivarius is almost as commonly present, although in smaller numbers. Like the other alpha- and non-haemolytic streptococci of the mouth, Str. salivarius is dispersed into the air in coughing and talking and also in simulated sneezes. In five experiments the air of a room was sampled after it had been contaminated with a 'spraying spit' (see Bourdillon et al. 1948); streptococci were present in very large numbers, and the ratio of Str. salivarius to other viridans-type streptococci was about 1:10. After coughing the proportion of Str. salivarius was rather larger, although the absolute numbers were far smaller.

Du Buy, Arnold \& Olson (1947) regarded streptococei as unsatisfactory indicators of respiratory pollution because the upper respiratory tract was not their sole source. Certainly, streptococci are found on clothing and also in the floor dust of occupied rooms (see, for example, table 9 in the report on the effect of irradiation, Air Hygiene Committee, 1954), but there seems no reason to think that they are not still derived from the upper respiratory tract of the past or present occupants, and to this extent are still a valid indication of past respiratory pollution. 
The consistent correlation of mouth streptococci with the amount of talking supports the thesis that, in schoolrooms, they are a useful index of recent pollution from mouth and respiratory tract. On several occasions in the classrooms when sneezing was noted a high count was observed. Singing, on the other hand, was not associated with a particularly high count (cf. Rubbo \& Benjamin, 1953). The streptococcal count was not highly correlated with activity in the schoolrooms, and on a few occasions when we made a special investigation during periods of activity unaccompanied by talking, we found no Str. salivarius in the air. Our observations do, nevertheless, suggest that a proportion of the streptococci found in the air come from secondary reservoirs and that these streptococci are less sensitive to ultra-violet irradiation. The proportion so derived appears to be greater for the older children, and it is possible that it might be a much larger or even a major proportion in other environments.

It is important to distinguish mouth streptococci both from faecal streptococci, which make up an average of $20 \%$ of the total streptococcal count, and from the aerococci which are generally more common than streptococci, and from which they can be distinguished only by microscopy or biochemical tests (Williams et al. 1953). Neither enterococci nor aerococci are found in the mouth, so that their presence in the air cannot be regarded as indicative of respiratory pollution.

Enterococci were common in floor dust but, since they were rare on the children's clothing, we do not think that their source is the intestinal tract of the children; and, indeed, by laying sheets of sterilized paper in the doorway and sampling them after the children had entered the school building, we were able to show that they are brought in from outdoor dust on shoes.

The two potential sources for the micrococci that make up the bulk of the air flora are floor-dust and clothing. We have no satisfactory evidence distinguishing their relative contributions, although we know that both can contribute. In a special experiment in which the floor was treated to lay the dust and about twenty children danced in the room for $3 \frac{1}{2}$ min., the general count reached 186 colonies/ cu.ft. On the other hand, in another experiment with the floor untreated we found it difficult to raise the bacterial count to any noteworthy extent when investigators wearing sterile clothing made rapid movements and stamped on the floor, although dust could of course be readily raised by blowing a jet of air on to the floor. Nevertheless, the relative sparsity of enterococci on clothing and their frequency in the air suggests that they, at least, are derived from floor dust.

\section{SUMMARY}

Air-borne bacteria collected from occupied schoolrooms and cultivated aerobically on serum agar yielded a mean count of 'general bacterial flora' (principally various micrococci) of about 70 colonies/cu.ft. with a $95 \%$ range of $19-251$ colonies/cu.ft. Of a number of other occupied places examined, none except busy public offices yielded as high an average count.

When the air samples were cultivated on a medium designed to suppress micrococci, a count of 1.0-1.5 colonies of streptococci/cu.ft. was observed. About $25 \%$ of the streptococci were levan-producing Streptococcus salivarius. 
An analysis was made of factors that might affect the number of bacteria found in the classroom air. The principal findings were that Str. salivarius was correlated with the amount of talking among the room occupants and that the general count was correlated with the ventilation rate and to a less extent with talking. Both counts were correlated less strongly with the general level of activity among the occupants.

In classrooms with ultra-violet irradiation, the numbers of Str. salivarius were reduced and the correlation with talking was less than in the unirradiated rooms, being little greater than the small correlation with activity.

It was concluded that most of the Str. salivarius in the air of the schoolrooms were derived directly from the upper respiratory tract of the occupants, and these seemed to be sensitive to ultra-violet irradiation. A smaller proportion were probably dispersed from secondary reservoirs and were less sensitive to the irradiation.

Most of the organisms comprised in the general bacterial flora were probably derived from such secondary reservoirs as clothing, but some, including the enterococci, were almost certainly derived from floor dust.

We are greatly indebted to Mrs Eileen Woods for her help in the computations on which this paper is based.

\section{REFERENCES}

Arr Hygiene Committee (1954). Air disinfection with ultra-violet irradiation. Spec. Sp. Rep. Ser. med. Res., Coun., Lond. no. 283.

Bourdillon, R. B., Lidwell, O. M. \& Lovelock, J. E. (1948). Studies in air hygiene. Spec. Rep. Ser. med. Res. Coun., Lond., no. 262.

Du BuY, H., ArNold, F. A. \& Olson, B. J. (1947). Studies on the air transmission of microorganisms derived from the respiratory tract. I. Lactobacillus acidophilus as a test organism. Publ. Hlth Rep., Wash., 62, 1391.

Gordon, M. H. (1904). Report on a bacterial test for estimating pollution of air. Report of the Medical Officer in 32nd Report of Local Government Board, 1902-3, p. 421. London.

Hrrch, ANn (1951). Bacterial contamination of the air in boot and shoe factories. Brit. J. industr. Med. 8, 8.

LIDWELL, O. M. \& LOVELOCK, J. E. (1946). Some methods of measuring ventilation. J. Hyg., Camb., 44, 326.

Reid, D. D., Lidweli, O. M. \& Williams, R. E. O. (1956). Counts of air-borne bacteria as indices of air hygiene. J. Hyg., Camb., 54, 524.

Rubbo, S. D. \& Benjamin, Mary (1953). Transmission of haemolytic streptococci. J. Hyg., Camb., 51, 278.

Sherman, J. M., Niven, C. F., Jr., \& SMtLey, K. L. (1943). Streptococcus salivarius and other non-haemolytic streptococci of the human throat. J. Bact. 45, 249.

Williams, R. E. O. (1956). Streptococcus salivarius (vel hominis) and its relation to Lancefield's Group K. J. Path. Bact. 72, 15.

Williams, R. E. O. \& Hincr, ANN (1950). The detection of streptococei in air. J. Hyg., Camb., 48, 504 .

Williams, R. E. O., Hirch, ANn \& Cowan, S. T. (1953). Aerococcus, a new bacterial genus. J. gen. Microbiol. 8, 475 .

Williams, R. E. O., Hirch, ANn \& Lidwell, O. M. (1950). Bacterial contamination of air in underground trains. Lancet, 1, 128.

(MS. received for publication 14. v. 56) 